\title{
THE EFFECT OF VARIOUS CLOVER MANAGEMENT PRACTICES ON GASEOUS N LOSSES AND MINERAL N ACCUMULATION'
}

\author{
M. S. AULAKH, D. A. RENNIE, and E. A. PAUL ${ }^{2}$ \\ Department of Soil Science, University of Saskatchewan, Saskatoon, Sask. \\ $S 7 N$ OWO. Saskatchewan Institute of Pedology Contribution no. R327, received 17 \\ Jan. 1983, accepted 12 Apr. 1983.
}

\begin{abstract}
Aulakh, M. S., Rennie, D. A. And Paul, E. A. 1983. The effect of various clover management practices on gaseous $\mathrm{N}$ losses and mineral $\mathrm{N}$ accumulation. Can. J. Soil Sci. 63: 593-605.
\end{abstract}

\begin{abstract}
A 2-yr field study was carried out to assess gaseous losses of $\mathrm{N}$ as $\mathrm{N}_{2} \mathrm{O}+\mathrm{N}_{2}$ from two Black Chernozemic soils, where during year 1 wheat was underseeded to clover and in year 2, the clover in late June was (a) green-manured and the field fallowed, (b) harvested for hay and then fallowed, or (c) harvested for hay and allowed to regrow. Gaseous losses during year 1 were small and ranged from 1.3

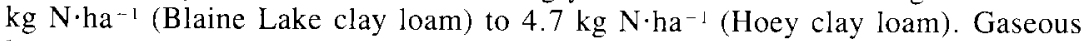
losses were somewhat higher during the second year, but differences between the various clover management practices were generally small. The contribution of lower soil horizons towards gaseous nitrogen losses were shown to be negligible. Soil moisture, mean air temperature, nitrate + nitrite, and ammonia $\mathrm{N}$ concentrations collectively accounted for $37-66 \%$ of the variations in $\mathrm{N}_{2} \mathrm{O}$ fluxes. It is concluded that incorporation of clover followed by a partial fallow results in substantially less gaseous loss of nitrogen than the standard summerfallowing practice, and at the same time significantly increases mineral nitrogen accumulation in the soil.

Key words: Acetylene inhibition technique, denitrification, nitrification, mineralization, green manuring
\end{abstract}

[Effets de diverses pratiques de culture du trèfle sur les pertes d'azote gazeux et l'accumulation d'azote minéral.]

Titre abréga: Modification du taux de dénitrification par les pratiques culturales du trèfle.

Une étude de deux ans au champ a permis de mesurer les pertes d'azote gazeux sous forme de $\mathrm{N}_{2} \mathrm{O}$ et de $\mathrm{N}_{2}$ dans deux chernozems noirs. On a (a) récolté le trèfle pour l'affouragement en vert puis mis le champ en jachère, (b) récolté le foin de trèfle et laissé le champ en jachère ou (c) récolté le foin et laissé le trèfle repousser. Les pertes gazeuses enregistrées la première année étaient assez faibles (de 1,3 kg de $\mathrm{N}$ par ha sur loam argileux Blaine Lake à $4,7 \mathrm{~kg}$ sur loam argileux Hoey). Les pertes étaient légèrement plus élevées la seconde année, mais les écarts entre les différents traitements étaient généralement minimes. Il esemble que les horizons inférieurs du sol aient un effet négligeable sur les pertes d'azote sous forme gazeuse. La teneur en eau du sol, la température moyenne de l'air et la concentration de nitrates et de nitrites ainsi que d'azote ammoniacal expliquent collectivement de 37 à $66 \%$ des pertes de $\mathrm{N}_{2} \mathrm{O}$. On en conclut que l'incorporation du trèfle au sol suivie par une jachère partielle entraîne une perte d'azote gazeux sensiblement

${ }^{1}$ This paper was presented at the Annual Meeting of the Canadian Society of Soil Science, 10-14 July 1983, Truro, Nova Scotia.

${ }^{2}$ Present address (E.A.P.): Department of Plant and Soil Biology, University of California. Berkeley, Calif. 94720

Can. J. Soil Sci. 63: 593-605 (Aug. 1983) 
moins grande que la jachère d'été traditionnelle tout en augmentant sensiblement l'accumulation d'azote minéral dans le sol.

Mots clés: Technique d'inhibition à l'acétylène, dénitrification, nitrification, minéralisation, affouragement en vert

Summerfallowing, a common practice in the Canadian Prairies has been criticized for accelerating organic matter decomposition and increasing erodibility and salinity of soils (Campbell and Biederbeck 1980; Rennie et al. 1980). Furthermore, our recent studies have shown that gaseous losses of nitrogen are twofold to fivefold higher from summerfallowed than cropped fields (Chatarpaul et al. 1980; Aulakh et al. 1982a,b, 1983). All of these factors as well as the ever-increasing need for and cost of nitrogenous fertilizers have lead to the recent interest in the use of annual or biennial legumes as soil-improving crops (Rennie 1979; Johnson 1980; Grevers and de Jong 1982). One of the alternatives to summerfallow as now practiced is growing wheat underseeded to clover and incorporating the clover as a green manure in the fallow year. The increased water used by clover which formerly discouraged this practice may possibly be overcome by snow management techniques (de Jong and Paul 1982).

The purpose of this investigation was to assess gaseous $\mathrm{N}$ losses and mineral $\mathrm{N}$ accumulation in cropping systems which included wheat underseeded to clover, followed in the second year by a selected number of clover management practices.

\section{MATERIALS AND METHODS}

The experiments were carried out in conjunction with the continuous wheat versus wheatfallow experiments reported earlier (Aulakh et al. 1983); a summary of the more important characteristics of the Hoey clay loam and the Blaine Lake clay loam soils on which these experiments were established is given in Table 1. It should be noted that the properties of these soils are very similar to those reported by Aulakh et al. (1983), the 25-ha experimental fields for the experiments reported in this manuscript were adjacent fields and consequently there were minor differences in soil properties.
In May 1980, wheat was underseeded to clover with an application of $100 \mathrm{~kg} \mathrm{~N} \cdot \mathrm{ha}^{-1}$ (urea) on rapeseed stubble and wheat stubble land at the Hoey and Blaine Lake soil sites, respectively. In the following year, the clover was allowed to grow until late June, when three clover management practices were implemented. i.e.

(1) Green manured-fallow. The clover was worked into the soil as a green manure and the field was summerfallowed.

(2) Hayed-fallow. The clover was harvested for hay and the crowns and roots were worked into the soil and the field was summerfallowed. (3) Hayed-regrown. Clover was harvested and was removed for hay. Thereafter the clover was allowed to regrow and to act as a standing stubble to trap extra snow during the following winter.

A uniform area within the same field but without clover in 1981 was used as a check for interpreting the accumulation of $\left(\mathrm{NO}_{3}{ }^{-}+\mathrm{NO}_{2}^{-}\right)-\mathrm{N}$ from the mineralization of incorporated clover. $\mathrm{NH}_{4}{ }^{+}-\mathrm{N}$ was also measured but as its values were very small (2-4 $\left.\mu \mathrm{g} \cdot \mathrm{g}^{-1}\right)$ and were very similar in various plots, the data are not shown.

within each field in year 1 ; in year 2 , three replicate areas were chosen from each of the three clover management blocks. Gaseous N losses were measured weekly during June to mid-November of both years and again during the following springs.

The reader is referred to Aulakh et al. (1982a, 1983 ) for the details of the acetylene inhibition technique used to measure gaseous $\mathrm{N}$ losses $\left(\mathrm{N}_{2} \mathrm{O}+\mathrm{N}_{2}\right)$ from surface horizons and when assessing the contribution of lower soil horizons towards gaseous $\mathrm{N}$ losses. Reference is also made to the same publications for methods used to record soil and air temperatures, to measure soil moisture and mineral $\mathrm{N}\left(\mathrm{NO}_{3}{ }^{-}+\mathrm{NO}_{2}{ }^{-}\right.$, $\mathrm{NH}_{4}{ }^{+}$), and the assessment of potential denitrification rates and denitrifier counts (most probable number technique). Rainfall was recorded for both sites.

Multiple correlation coefficients were calculated to assess the relationship, if any, between gaseous $\mathrm{N}$ losses and soil moisture, mean air temperature, nitrate- $\mathrm{N}$ and ammonium- $\mathrm{N}$. 


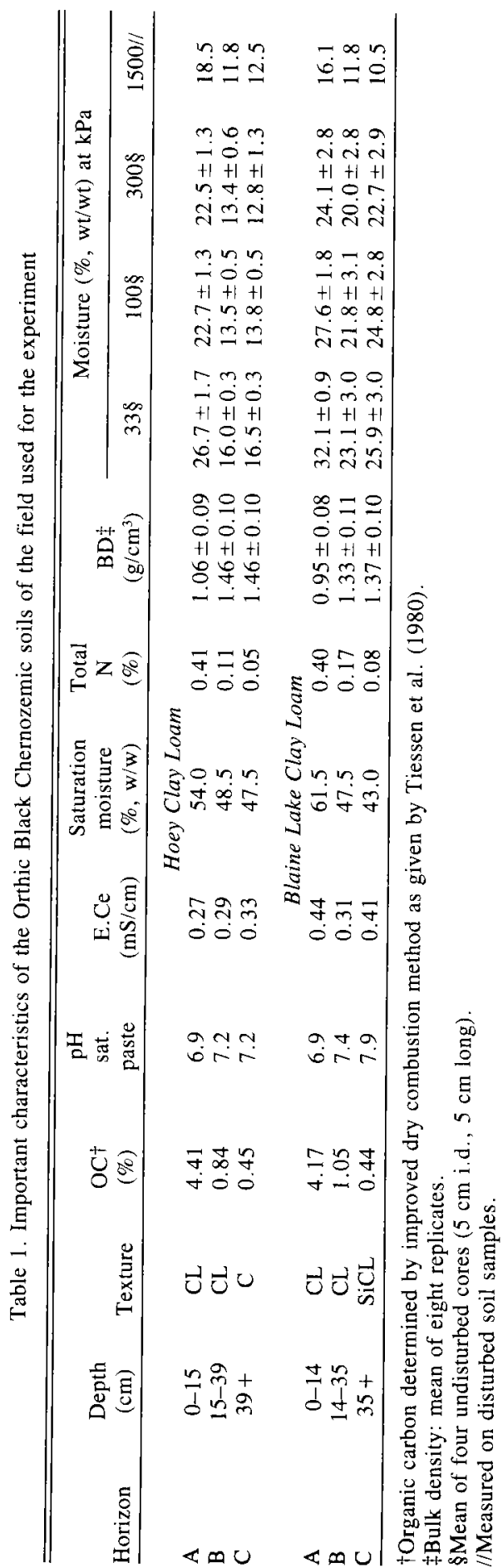

\section{RESULTS}

The emission of $\mathrm{N}_{2} \mathrm{O}-\mathrm{N}$ during the 1980 sampling period from both the Hoey clay loam and the Blaine Lake clay loam experimental sites, with certain exceptions, were very similar (Figs. 1 and 2). The exceptions, a severalfold increase in rate of $\mathrm{N}_{2} \mathrm{O}$ losses in late June at the Hoey site, and a relatively longer period of higher $\mathrm{N}_{2} \mathrm{O}$ evolution in August at the Blaine Lake as compared to the Hoey site are both associated with heavier precipitation and the resultant increase in soil moisture content.

The $\mathrm{NO}_{3}{ }^{-}-\mathrm{N}$ content was relatively high at the start of the 1980 growing season due primarily to fertilizer $\mathrm{N}$ additions; upon initiation of plant growth it dropped to below $10 \mu \mathrm{g} \cdot \mathrm{g}^{-1}$ and remained relatively constant for the remainder of the growing season (Figs. 1 and 2). Comparison of the mineral $\mathrm{N}$ trends with the $\mathrm{N}_{2} \mathrm{O}-\mathrm{N}$ evolution during the 1980 growing season indicated little if any relationship between gaseous $\mathrm{N}$ losses and the inorganic $\mathrm{N}$ content of the soil. Also, it is evident in the spring 1981 data that $\mathrm{N}_{2} \mathrm{O}-\mathrm{N}$ losses increased at both locations, but in particular on the Hoey clay loam while inorganic $\mathrm{N}$ contents at both locations were low and unchanged. In contrast, soil moisture contents which were initially high dropped quite rapidly due to the rapid growth of the clover. The peak in $\mathrm{N}_{2} \mathrm{O}$ losses was directly associated with high soil moisture, and the rate of $\mathrm{N}_{2} \mathrm{O}$ loss dropped sharply as the soil dried out.

The clover continued to grow until the end of June 1981, when it had attained a height of $90-100 \mathrm{~cm}$ and reached the flowering stage. At that time it was greenmanured or hayed and then fallowed for the remainder of the year, or hayed and the clover allowed to regrow. The $\mathrm{N}_{2} \mathrm{O}-\mathrm{N}$ evolution for the Hoey soil was much greater than that for the Blaine Lake soil (Figs. 3 and 4). This was associated with the 30 $\mathrm{mm}$ of precipitation in early July. In general, $\mathrm{N}$ losses during this period of relatively high moisture contents were highest on the green manured-fallow plots and 


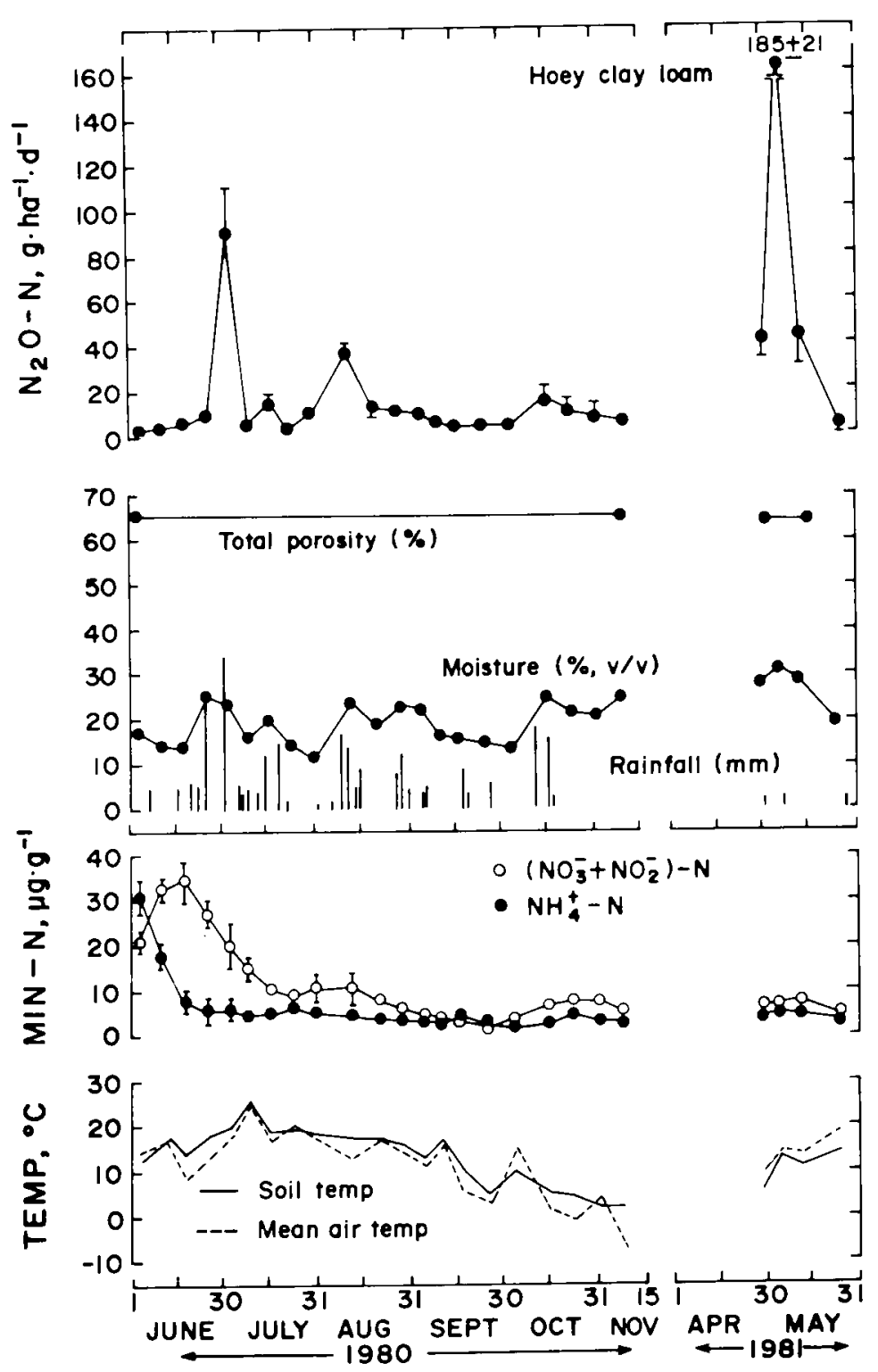

Fig. 1. Gaseous $\mathrm{N}$ loss $\left(\mathrm{N}_{2} \mathrm{O}-\mathrm{N}\right)$, soil moisture, rainfall, mineral $\mathrm{N}$ and air and soil temperature of Hoey clay loam with wheat underseeded to clover for the period June 1980-May 1981. Ф indicates SD.

least where the clover was allowed to regrow. This was not unexpected since the regrowth of the clover resulted in a lower moisture content.

Soil moisture directly affected air-filled porosity (total porosity minus volumetric moisture in Figs. 1-4). The role played by soil moisture is illustrated in the eightfold increase in $\mathrm{N}_{2} \mathrm{O}-\mathrm{N}$ losses measured in the green-manured-fallow plot at the Blaine 


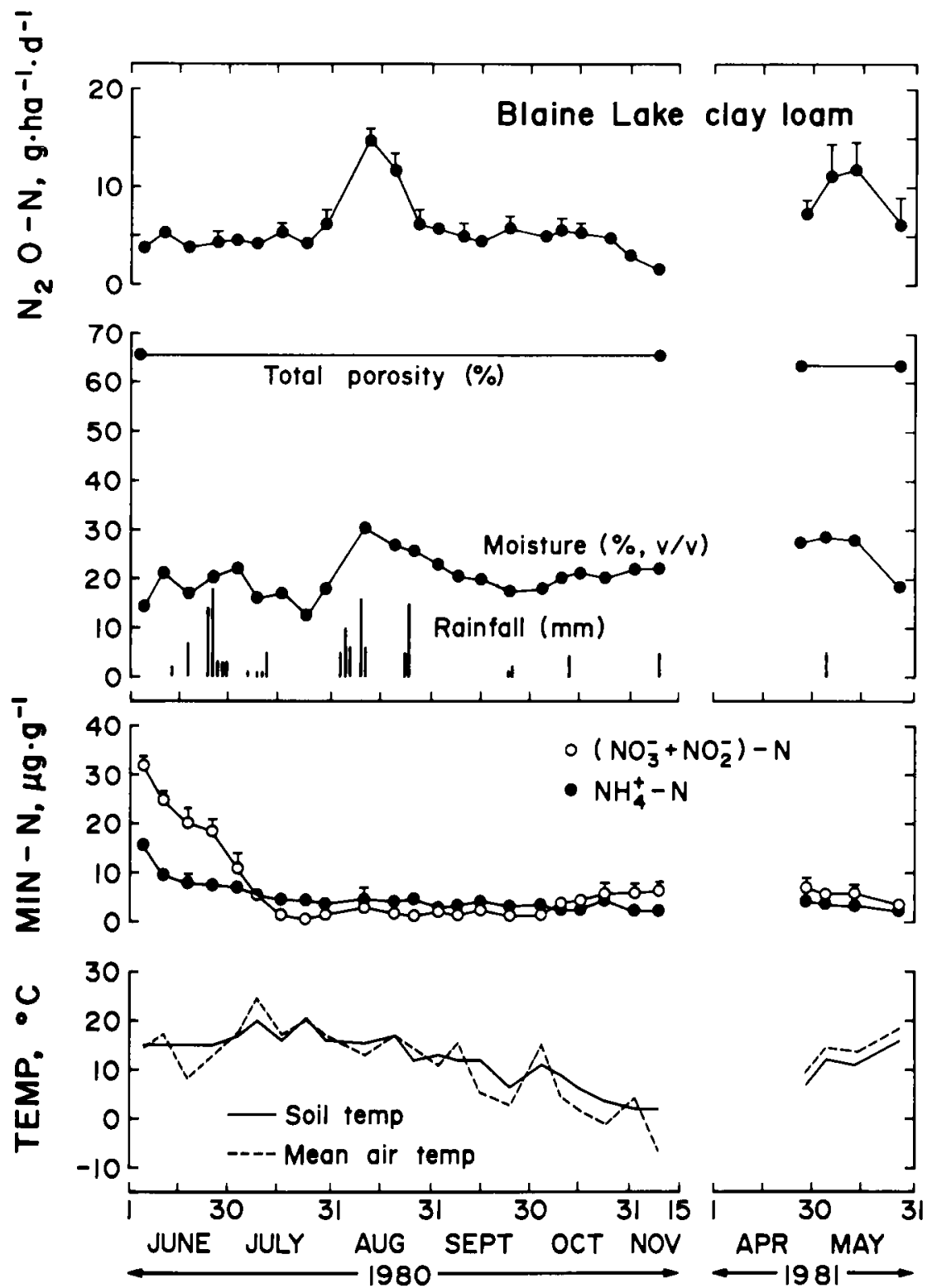

Fig. 2. Gaseous $\mathrm{N}$ loss $\left(\mathrm{N}_{2} \mathrm{O}-\mathrm{N}\right)$, soil moisture, rainfall, mineral $\mathrm{N}$ and air and soil temperature of Blaine Lake clay loam with wheat underseeded to clover for the period June 1980-May 1981. $\Phi$ indicates SD

Lake site in October, 1981 (Fig. 4). This was associated with a 20 -mm rainfall event; in contrast, the surface soil moisture content at the time of this rain was lower on the plot where the clover was allowed to regrow after haying and $\mathrm{N}_{2} \mathrm{O}$ emission was only increased slightly.

The $\mathrm{NO}_{3}^{-}-\mathrm{N}$ content increased rapidly 

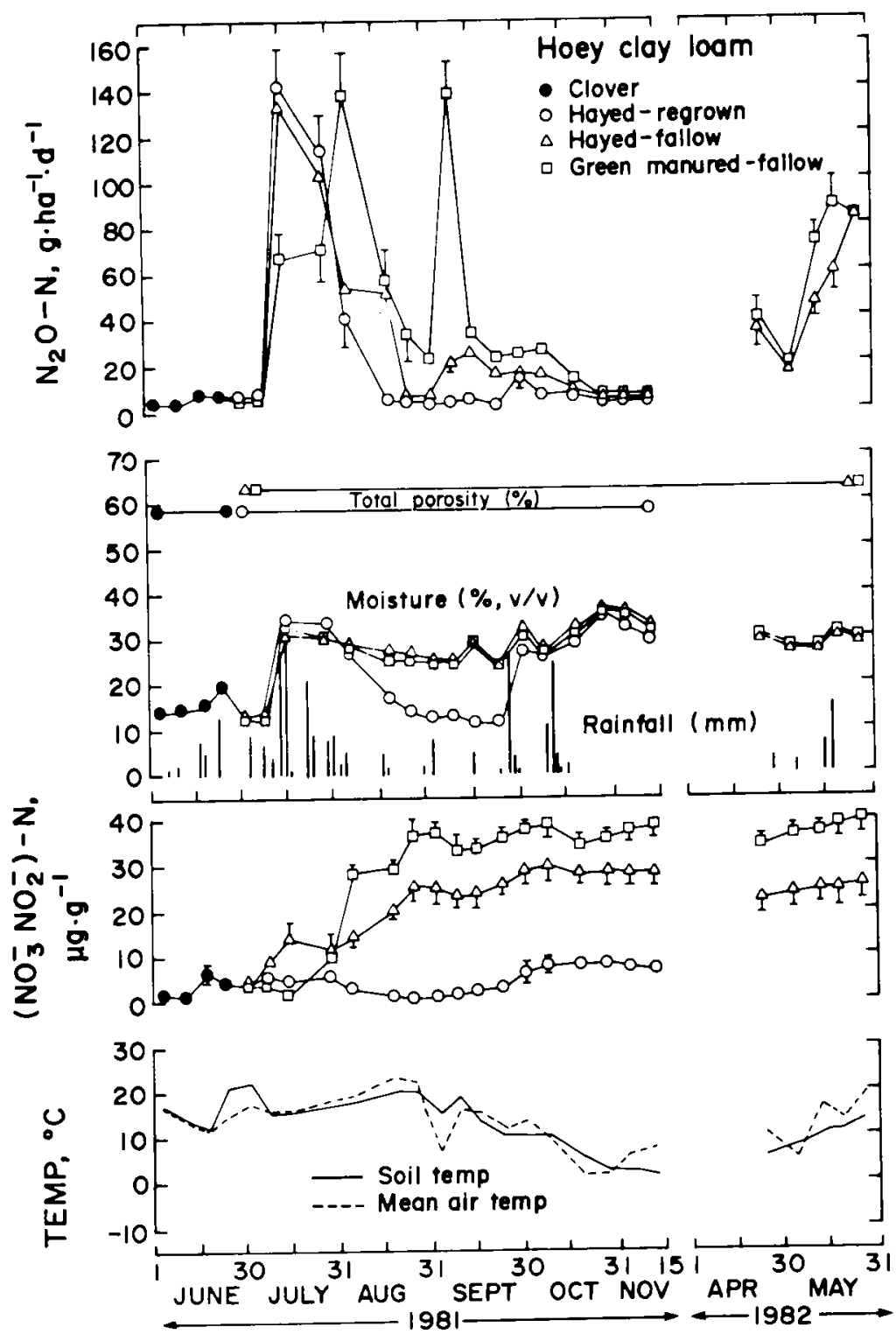

Fig. 3. Gaseous $\mathrm{N} \operatorname{loss}\left(\mathrm{N}_{2} \mathrm{O}-\mathrm{N}\right)$, soil moisture, rainfall, mineral $\mathrm{N}$ and air and soil temperature of Hoey clay loam under clover until late June 1981, followed by different clover treatments till May 1982. $\Phi$ indicates SD.

for both the green manured-fallow and hayed-fallow plots on the Hoey clay loam soil, reaching a maximum during the last week of August. In contrast, presumably due to the very much drier soil conditions on the Blaine Lake soil, significant increases in the $\left(\mathrm{NO}_{3}^{-}+\mathrm{NO}_{2}^{-}\right)$- $\mathrm{N}$ content did not occur until late September, and reached a maximum in the following spring. In the spring of 1982 , even though 

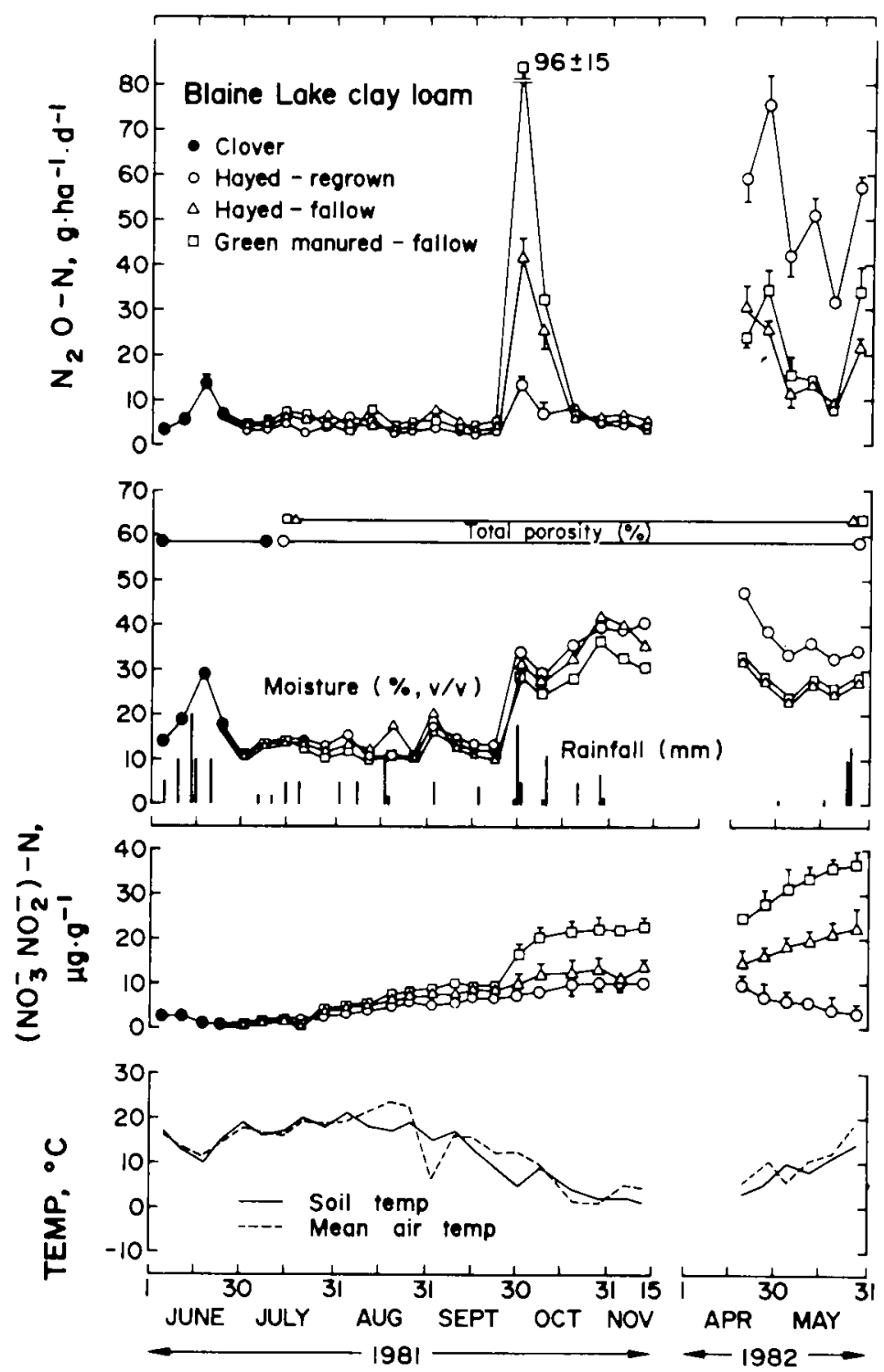

Fig. 4. Gaseous $\mathrm{N}$ loss $\left(\mathrm{N}_{2} \mathrm{O}-\mathrm{N}\right)$, soil moisture, rainfall, mineral $\mathrm{N}$ and air and soil temperature of Blaine Lake clay loam under clover until late June 1981, followed by different clover treatments period till May 1982. $\Phi$ indicates SD.

the inorganic $\mathrm{N}$ content was much higher on the green manured-fallow than on the hayed-fallow plots, $\mathrm{N}_{2} \mathrm{O}$ emissions were similar; this is in accord with similar soil moisture contents under these two treatments
Data were not obtained from the hayedregrown plot (Hoey soil) in the spring of 1982 because the cooperating farmer inadvertently cultivated this plot in the late fall of 1981. On the Blaine Lake soil the hayed-regrown plot evolved by far the 
largest amount of $\mathrm{N}_{2} \mathrm{O}-\mathrm{N}$, while the hayedfallow and green-manured-fallow plots evolved statistically similar amounts of $\mathrm{N}_{2} \mathrm{O}-\mathrm{N}$. This would appear to be due primarily to the much higher soil moisture contents on the hayed-regrown plots since the inorganic nitrogen content of this treatment was very much lower than that of either of the other two treatments.

In May 1982, samples were taken from the $\mathrm{A}, \mathrm{B}$ and $\mathrm{C}$ horizons of the several plots on the Hoey and Blaine Lake soils to assess the relative amount of gaseous $\mathrm{N}$ losses occurring from surface and subsurface horizons (Table 2). The data obtained at sampling times I and II indicate that while $\mathrm{N}_{2} \mathrm{O}$ evolution from $\mathrm{B}$ and $\mathrm{C}$ horizon material is low, it can constitute a significant part of the total $\mathrm{N}_{2} \mathrm{O}$ evolved when losses from the A horizon are low or depressed. A more realistic comparison, however, was obtained from the samples taken at sampling time III; each sample was moistened up to a constant moisture content (approximately $10-\mathrm{kPa}$ moisture tension) prior to incubation. Under these conditions $\mathrm{N}_{2} \mathrm{O}-\mathrm{N}$ loss from the subsurface horizons was only a small percentage of that of the A horizon. This observation was verified by the potential denitrification rate values and denitrifier counts. These data suggest that in general losses of $\mathrm{N}_{2} \mathrm{O}$ from subsurface horizons are much lower than from surface horizons. The results of this field study support the findings of Cho et al. (1975) who found drastic decreases in the magnitude of denitrification with soil depth in a laboratory study. Thus, in field studies, gaseous losses of $\mathrm{N}$ from subsurface horizons need not be measured where the object of the study is to assess the effect of soil and crop management practices on the comparative rates of denitrification.

\section{DISCUSSION}

The cumulative $\mathrm{N}$ losses for the various clover management practices (1981-1982) are approximately twice as high as where wheat underseeded to clover (1980-1981) was grown (Table 3). The higher level of $\mathrm{N}_{2} \mathrm{O}-\mathrm{N}$ losses on the Hoey clay loam can only be attributed in part to the more favorable moisture conditions prevailing at this location during both the 1981 and 1982 growing seasons; both the potential denitrification rate values and denitrifier counts clearly characterize the greater potential for denitrification on Hoey as compared to the Blaine Lake soil.

Even under the drier-than-normal conditions which prevailed at both sites, but which were more severe at the Blaine Lake site, the loss of $\mathrm{N}$ as gaseous $\left(\mathrm{N}_{2} \mathrm{O}+\mathrm{N}_{2}\right)$ $\mathrm{N}$ was significantly higher where the clover had been green manured in comparison to where it had been removed and the soil fallowed. While the higher gaseous losses are associated with higher levels of soil $\mathrm{NO}_{3}{ }^{-}-\mathrm{N}$, it has been shown that the addition of easily decomposable carbon materials with a lower $\mathrm{C}: \mathrm{N}$ ratio greatly enhance denitrification (Guenzi et al. 1978; Aulakh and Rennie 1983). Where the hay was allowed to regrow the over-winter capture of snow water was very much larger (Fig. 4) and consequently in the spring of 1982 on the Blaine Lake clay loam soil, the losses of gaseous $\mathrm{N}$ were severalfold higher on this treatment than either of the other two. Unfortunately it was not possible to substantiate a similar trend on the Hoey clay loam soil because the farmer inadvertently had fall-tilled this portion of the field.

The amount of plant material, including tops, crowns and roots added in greenmanured plots on the Hoey and Blaine Lake soils was $127 \pm 14$ and $119 \pm 5 \mathrm{~kg}$ $\mathrm{N} \cdot \mathrm{ha}^{-1}$, respectively (de Jong and Paul 1982). While mineralization was substantially higher at the Hoey site during the August-September 1981 period, by the end of May 1982 (before seeding next crop) net accumulation of mineral $\mathrm{N}$ over and above the check plots was similar at both locations and approximately $50 \mathrm{~kg} \mathrm{~N} \cdot \mathrm{ha}^{-1}$ (Fig. 5). This represents about $40 \%$ of $N$ added as clover residues. In a recent field 


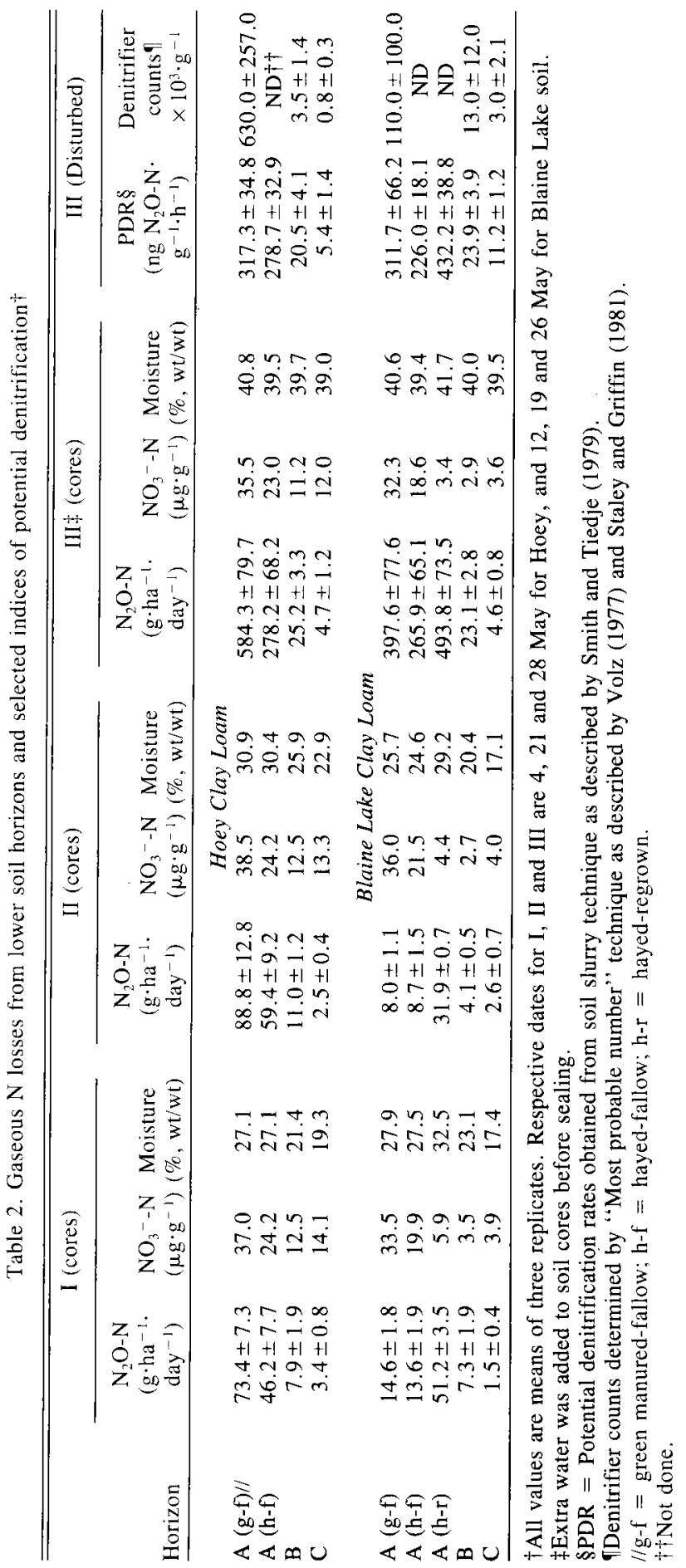




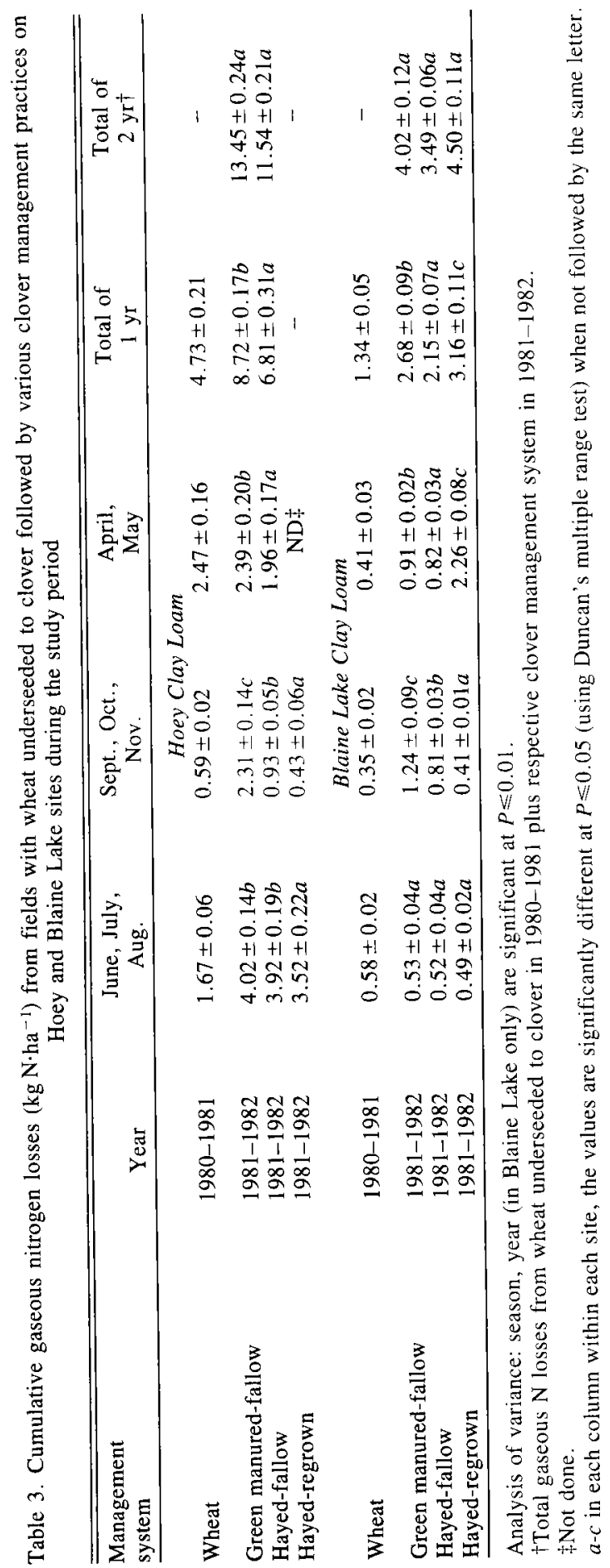




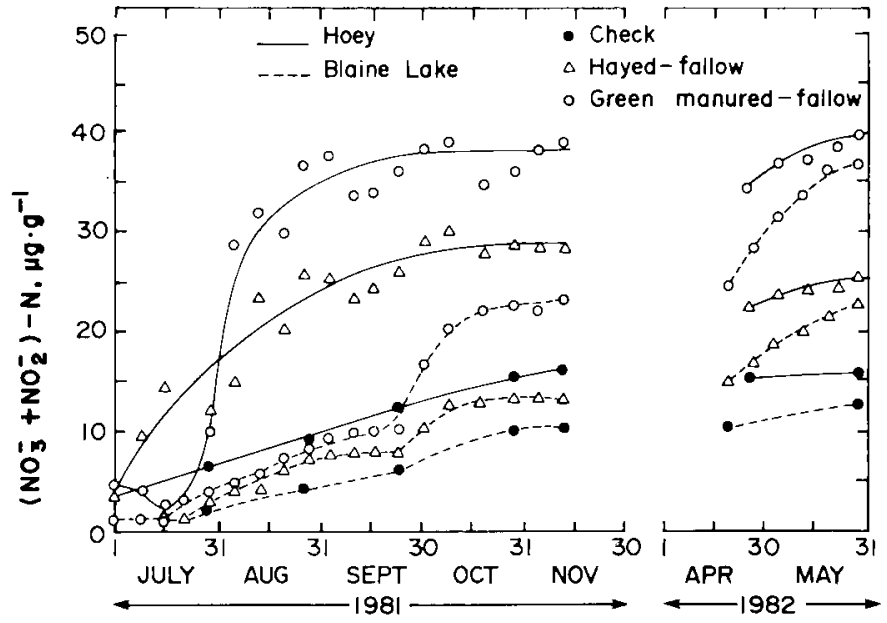

Fig. 5. Accumulation of $\left(\mathrm{NO}_{3}{ }^{-}+\mathrm{NO}_{2}{ }^{-}\right)-\mathrm{N}$ in soil $(0-15 \mathrm{~cm})$ from the decomposition of clover residues incorporated in green manured-fallow and hayed-fallow plots, in comparison to that from the check plots.

study on the decomposition of ${ }^{15} \mathrm{~N}$-labelled legume material, Ladd et al. (1981) have shown that $35-40 \%$ of $\mathrm{N}$ added as legume residues became available during an 8 -mo fallow period. This is very close to the estimates given above.

During this 2-yr study, a number of environmental parameters including soil moisture, air temperature and the concentration of $\left(\mathrm{NO}_{3}{ }^{-}+\mathrm{NO}_{2}{ }^{-}\right)-\mathrm{N}$ and $\mathrm{NH}_{4}{ }^{+}-\mathrm{N}$ were measured at each of the weekly sam- pling times. A multiple correlation analysis was carried out to determine which of these variables or groups of variables were primarily responsible for changes in gaseous $\mathrm{N}$ losses (Table 4). Moisture and temperature were clearly the most significant variables affecting $\mathrm{N}_{2} \mathrm{O}$ losses. When all data obtained at temperatures less than $5^{\circ} \mathrm{C}$ were excluded, temperature was no longer a significant factor. Nitrate levels, in general, did not improve the correlation coef-

Table 4. Multiple correlation coefficients of gaseous $\mathrm{N}$ losses $\left(\mathrm{g} \mathrm{N}_{2} \mathrm{O}-\mathrm{N} \cdot \mathrm{ha}^{-1} \cdot \mathrm{day}^{-1}\right)$ with different parameters

\begin{tabular}{|c|c|c|c|c|}
\hline \multirow{2}{*}{$\begin{array}{l}\text { Using data } \\
\text { at air temp. }\end{array}$} & \multicolumn{4}{|c|}{$R \dagger$ value with parameters $\ddagger$} \\
\hline & M & $\mathrm{M}+\mathrm{T}$ & $\mathrm{M}+\mathrm{T}+\mathrm{N}$ & $\mathrm{M}+\mathrm{T}+\mathrm{N}+\mathrm{A}$ \\
\hline & \multicolumn{4}{|c|}{ Hoey Clay Loam } \\
\hline All & 0.478 & 0.658 & 0.664 & 0.665 \\
\hline$>5^{\circ} \mathrm{C}$ & 0.683 & 0.709 & 0.713 & 0.713 \\
\hline$>10^{\circ} \mathrm{C}$ & 0.706 & 0.719 & 0.725 & 0.725 \\
\hline \multirow[t]{2}{*}{$>15^{\circ} \mathrm{C}$} & 0.802 & 0.810 & 0.810 & 0.810 \\
\hline & \multicolumn{4}{|c|}{ Blaine Lake Clay Loam } \\
\hline All & 0.525 & 0.588 & 0.591 & 0.604 \\
\hline$>5^{\circ} \mathrm{C}$ & 0.716 & 0.722 & 0.724 & 0.732 \\
\hline$>10^{\circ} \mathrm{C}$ & 0.673 & 0.678 & 0.681 & 0.691 \\
\hline$>15^{\circ} \mathrm{C}$ & 0.748 & 0.761 & 0.769 & 0.811 \\
\hline
\end{tabular}

$\dagger$ All multiple correlation coefficients significant at $P \leqslant 0.01$.

$\ddagger$ Parameters: $\mathrm{M}=$ moisture $(\%, \mathrm{vol} / \mathrm{vol}) \mathrm{T}=$ mean air temperature $\left({ }^{\circ} \mathrm{C}\right), \mathrm{N}=$ nitrate- $\mathrm{N}\left(\mu \mathrm{g} \cdot \mathrm{g}^{-1}\right), \mathrm{A}=$ ammonium-N $\left(\mu \mathrm{g} \cdot \mathrm{g}^{-1}\right)$. 
ficients even though the range in $\mathrm{NO}_{3}{ }^{-}-\mathrm{N}$ in the various treatments was relatively large.

\section{CONCLUSIONS}

This 2-yr study has confirmed that gaseous losses of nitrogen on Black Chernozemic soils seeded to wheat were relatively low under the drier-than-normal conditions which prevailed in these years. While $\mathrm{N}$ losses were somewhat higher for the various clover management practices, differences between the several tillage treatments were small; the largest gaseous losses occurred where the clover was green manured in late June and summerfallowed for the remainder of the year. The contribution of lower soil horizons towards gaseous $\mathrm{N}$ losses in contrast to losses from surface soil horizons was low, particularly when the moisture content was increased above the undisturbed field capacity level. Soil moisture was shown from these experiments to be the major variable controlling rate of gaseous $\mathrm{N}$ losses while nitrate concentrations were, in general, insignificant. Mean air temperature only exerted a significant effect as it approached a level, i.e. $5^{\circ} \mathrm{C}$, that sharply reduced microbial activity.

It is concluded from these studies that the incorporation of clover followed by a partial fallow results in substantially less gaseous $\mathrm{N}$ losses than the standard summerfallow practice measured at the same sites (Aulakh et al. 1983) and at the same time significantly increases mineral nitrogen accumulation in the soil; approximately $40 \%$ of the $\mathrm{N}$ added as clover residues in the green manured treatment was mineralized by the end of the fallow period.

\section{ACKNOWLEDGMENTS}

This study was supported by the Natural Sciences and Engineering Research Council of Canada, and the senior author was supported by the Canadian Scholarship and Fellowship Committee.

AULAKH, M. S. and RENNIE, D. A. 1983. The influence of nitrogen-immobilization on denitrification rates in conventional and zerotill soils. In Agronomy abstracts, Annual Meetings Am. Soc. Agron., 14-19 Aug. 1983. Washington, D.C. AULAKH, M. S., RENNIE, D. A. and PAUL, E. A. 1982a. Gaseous nitrogen losses from cropped and summerfallowed soils. Can. J. Soil Sci. 62: 187-195.

AULAKH, M. S., RENNIE, D. A. and PAUL, E. A. 1982b. Gaseous $\mathrm{N}$ losses from soils under zero-till as compared to conventional-till. Page 183 in Agronomy abstracts, Annual Meetings, Am. Soc. Agron., 28 Nov.-3 Dec. 1982. Anaheim, Calif.

AULAKH, M. S., RENNIE, D. A. and PAUL, E. A. 1983. Field studies on gaseous nitrogen losses from soils under continuous wheat versus a wheat-fallow rotation. Plant Soil 75: (in press)

CAMPBELL, C. A. and BIEDERBECK, V. O. 1980. Changes in the quality of soils of the prairies as a result of agricultural production. Presented at Prairie Production Symposium, 29-31 Oct. 1980. Canadian Wheat Board Advisory Committee, Saskatoon, Sask.

CHATARPAUl, L., PAUl, E. A. and COLACO, W. 1980. Denitrification in Saskatchewan soils under field conditions. In Abstracts of 80th Annual Meeting of Am. Soc. Microbiol. 11-16 May 1980. Miami Beach, Fla.

CHO, C. M., SAKDINAN, L. and CHANG, C. 1975. Denitrification intensity and capacity of three irrigated Alberta soils. Soil Sci. Soc. Am. J. 43: 945-950.

DE JONG, E. and PAUL, E. A. 1982. Final report on the project "The management of nitrogen and water in innovative farming systems," submitted to Natural Sciences and Engineering Research Council of Canada, Ottawa, Ontario, Canada.

GREVERS, M. and DE JONG, E. 1982. The effect of traditional versus innovative farming on soil structure. Pages 49-67 in Proc. 1982 Soils and Crops Workshop, AgDex 510, Publ. no. 464, Extension Division, Univ. of Saskatchewan, Saskatoon, Sask.

GUENZI, W. D., BEARD, W. E., WATANABE, F. S.. OLSEN, S. R. and PORTER, L. K. 1978. Nitrification and denitrification in cattle manure-amended soil. J. Environ. Qual. 7: 196-202.

JOHNSON, W. E. 1980. Potential production to 1990, Western Canada; Cereals, Oilseeds 
and Forage. Canada West Foundation, Calgary, Publ. no. 80-132. 63 pp.

LADD, J. N., OADES, J. M. and AMATO, M. 1981. Microbial biomass formed from ${ }^{14} \mathrm{C}$, ${ }^{15} \mathrm{~N}$-labelled plant material decomposing in soils in the field. Soil Biol. Biochem. 13: 119-126. RENNIE, D. A. 1979. More efficient soil management. In Proc. Western Canada Fertilizer Association Meetings, Richmond, B.C.

RENNIE, D. A., BEATON, J. D. and HEDLIN, R. A. 1980 . The role of fertilizer nutrients in Western Canadian agricultural development. Canada West Foundation, Calgary, Publ. 80-139. 95 pp.

SMITH, M. S. and TIEDJE, J. M. 1979.

Phases of denitrification following oxygen de- pletion in soil. Soil Biol. Biochem. 11: 261-267.

STALEY, T. E. and GRIFFIN, J. B. 1981. Simultaneous enumeration of denitrifying and nitrate reducing bacteria in soil by a microtiter most-probable-number (MPN) procedure. Soil Biol. Biochem. 13: 385-388.

TIESSEN, H., BETTANY, J. R. and STEWART, J. W. B. 1980. An improved method for the determination of carbon in soils and soil extracts by dry combustion. Commun. Soil Sci. Plant Anal. 12: 211-218.

VOLZ, M. G. 1977. Denitrifying bacteria can be enumerated in nitrite broth. Soil Sci. Soc. Am. J. 41: 549-551. 